\title{
Long-Term Persistence of IgG Antibodies in SARS-CoV Infected Healthcare Workers
}

4 Xiaoqin Guo ${ }^{1, \#}$, Zhongmin Guo ${ }^{2, \#}$, Chaohui Duan, ${ }^{3, \#}$, Zeliang Chen ${ }^{1 \#}$, Guoling Wang ${ }^{1}, \mathrm{Yi} \mathrm{Lu}^{4}$, Mengfeng

$5 \mathrm{Li}^{5}$, Jiahai $\mathrm{Lu}^{1, *}$

6

$7 \quad{ }^{1}$ One Health Center, School of Public Health, Sun Yat-sen University, Guangzhou, 510080, P. R.

8 China

$9 \quad{ }^{2}$ Animal Experiment Center, Sun Yat-sen University, 510080, P. R. China

$10{ }^{3}$ Clinical Laboratory, The Sun Yat-sen Memorial Hospital, Sun Yat-sen University, Guangzhou,

11 510080, P. R. China

$12{ }^{4}$ Department of Health Law, Policy and Management, School of Public Health, Boston University,

13 USA.

$14{ }^{5}$ Department of Microbiology, Zhongshan School of Medicine, Sun Yat-sen University, 510080, P. R.

15 China

17 \# the authors contributed equally to this work

$18 *$ Corresponding author. lujiahai@mail.sysu.edu.cn for Jiahai Lu. 
medRxiv preprint doi: https://doi.org/10.1101/2020.02.12.20021386; this version posted February 14, 2020. The copyright holder for this preprint (which was not certified by peer review) is the author/funder, who has granted medRxiv a license to display the preprint in It is made available under a CC-BY-ND 4.0 International license.

\section{ABSTRACT}

\section{BACKGROUND}

25 The ongoing worldwide outbreak of the $2019-\mathrm{nCoV}$ is markedly similar to the severe acute

26 respiratory syndrome (SARS) outbreak 17 years ago. During the 2002-2003 SARS outbreak,

27 healthcare workers formed a special population of patients. Although virus-specific IgG play

28 important roles in virus neutralization and prevention against future infection, limited information is

29 available regarding the long term persistence of IgG after infection with SARS-like coronavirus.

\section{METHODS}

31 A long-term prospective cohort study followed 34 SARS-CoV-infected healthcare workers from a

32 hospital with clustered infected cases during the 2002-2003 SARS outbreak in Guangzhou, China,

33 with a 13-year follow-up. Serum samples were collected annually from 2003-2015. Twenty

34 SARS-CoV-infected and 40 non-infected healthcare workers were enrolled in 2015, and their serum

35 samples were collected. All sera were tested for IgG antibodies with ELISA using whole virus and a

36 recombinant nucleocapsid protein of SARS-CoV, as a diagnostic antigen.

\section{RESULTS}

38 Anti SARS-CoV IgG was found to persist for up to 12 years. IgG titers typically peaked in 2004,

39 declining rapidly from 2004-2006, and then continued to decline at a slower rate. IgG titers in 
medRxiv preprint doi: https://doi.org/10.1101/2020.02.12.20021386; this version posted February 14, 2020. The copyright holder for this preprint (which was not certified by peer review) is the author/funder, who has granted medRxiv a license to display the preprint in It is made available under a CC-BY-ND 4.0 International license.

40 SARS-CoV-infected healthcare workers remained at a significantly high level until 2015. Patients

41 treated with corticosteroids at the time of infection were found to have lower IgG titers than those

42 without.

\section{CONCLUSIONS}

44 IgG antibodies against SARS-CoV can persist for at least 12 years. The presence of SARS-CoV IgG

45 might provide protection against SARS-CoV and other betacoronavirus. This study provides valuable

46 information regarding humoral immune responses against SARS-CoV and the 2019-nCoV.

47

48 Keywords: SARS-CoV; IgG antibodies; Cohort Study

49 
medRxiv preprint doi: https://doi.org/10.1101/2020.02.12.20021386; this version posted February 14,2020 . The copyright holder for this preprint (which was not certified by peer review) is the author/funder, who has granted medRxiv a license to display the preprint in It is made available under a CC-BY-ND 4.0 International license.

\section{1. INTRODUCTION}

51 On December 31, 2019, an outbreak of coronavirus causing infections in Wuhan, China, was officially

52 reported. The outbreak rapidly spread to several provinces of China and other countries. Currently, the

53 ongoing outbreak in China caused by a new coronavirus, named 2019-nCoV by WHO, is becoming a

54 global crisis. Notably, the $2019-\mathrm{nCoV}$ is highly similar to the severe acute respiratory syndrome

55 coronavirus (SARS-CoV), which is characterized by high mortality and infectivity. Therefore,

56 information on SARS-CoV will be valuable for the prevention and control of the current outbreak.

57 SARS was first confirmed in Guangdong, China in 2002-2003, and subsequently became a pandemic,

58 spreading rapidly to 31 countries and regions, causing panic and a global public health crisis. ${ }^{1-3}$ In

59 total, 8,422 SARS cases were reported to the World Health Organization (WHO) with a case fatality

60 rate of $10.88 \%(916 / 8,422)$; of these total cases, 5,327 cases and 349 deaths were reported from 29

61 provinces of China. Guangdong was among the most affected provinces, with 1,511 reported cases,

$6222.90 \%(346 / 1,511)$ of which occurred in healthcare workers. ${ }^{3-5}$ During emergency disease control,

63 frontline healthcare workers, including physicians, nurses, and other healthcare workers, who were

64 exposed to the virus while treating and caring for SARS patients in the early stages of the outbreaks,

65 were mainly affected. During the later stages of the outbreak, although precautions to prevent the

66 infection were enhanced, infection of healthcare workers still occurred. ${ }^{6,7}$ No natural SARS-CoV

67 infections have been identified since the last confirmed case in May $2004 .^{8}$ The reasons why SARS 
medRxiv preprint doi: https://doi.org/10.1101/2020.02.12.20021386; this version posted February 14,2020 . The copyright holder for this preprint (which was not certified by peer review) is the author/funder, who has granted medRxiv a license to display the preprint in It is made available under a CC-BY-ND 4.0 International license.

69 concerns that SARS-CoV will re-emerge in the future; consequently, studies are underway to

70 determine the mechanisms through which SARS-CoV interacts with the host immune system, crosses

71 host barriers, and other related aspects.

72 SARS-CoV was initially identified as having occurred through interspecies transmission from small

73 carnivores (e.g., palm civets and raccoon dogs) to humans in $2003 .{ }^{10}$ Recently, studies indicate that

74 SARS-CoV may have originated from bats. Bat coronavirus isolates have been shown to be able to

75 recognize both human and bat ACE2 receptors. ${ }^{11}$ Coronaviruses can exploit numerous cellular

76 receptors and potentially cause various illnesses such as respiratory and gastrointestinal diseases. ${ }^{12}$

77 Particularly, the spike protein is an important viral determinant of virus-receptor interaction, interspecies transmission, and host tropism, and its mutation can facilitate cross-species infection and human-to-human transmission. ${ }^{13}$ Another novel coronavirus similar to SARS-CoV, the middle-east respiratory syndrome coronavirus (MERS-CoV), emerged in the Middle East in 2012. MERS-CoV has been shown to be transmissible from camels to humans, highlighting the ongoing threat posed by

82 SARS-CoV or other SARS-like viruses. ${ }^{14,15}$

83 SARS-CoV IgG antibodies have neutralization activities and provide protection against infections.

84 Presence of IgG antibodies against virus and nucleocapsid protein represents protective immune responses. While some previous studies reported longitudinal profiles of SARS IgG antibodies for up to 5 years, ${ }^{16-20}$ there has been a lack of knowledge on humoral immune responses for longer durations.

87 In our current study, we conducted a 13-year follow-up study on a cohort of SARS-CoV-infected 
medRxiv preprint doi: https://doi.org/10.1101/2020.02.12.20021386; this version posted February 14,2020 . The copyright holder for this preprint (which was not certified by peer review) is the author/funder, who has granted medRxiv a license to display the preprint in

It is made available under a CC-BY-ND 4.0 International license .

\section{2. METHODS}

\section{$90 \quad 2.1$ STUDY SITE AND PARTICIPANT ENROLLMENT}

91 The study site was a teaching hospital and the main center for treating clustered SARS cases in

92 2002-2003 in Guangzhou, China. The hospital employed 4,797 staff, possessed 2,140 annual open

93 beds, and treated over 3.2 million patients annually. During the outbreak (from February to March,

94 2003), a total of 95 healthcare workers, out of all the staff in this hospital, were diagnosed with SARS

95 according to the diagnostic criteria promulgated by the Health Bureau of Guangdong (published on

96 February 3, 2003), and 34 of these cases were enrolled in this study. The majority of the participants

97 were aged between 20 and 30, in 2003, and 94.11\% (32/34) of them were females (Table S1). The

enrollment criteria included clinical diagnosis of SARS-CoV infection in a healthcare worker treated

in the above mentioned hospital, the date of onset being prior to April 16, 2003, and an estimated

long-term follow-up of more than 9 years.

101

The sera used in this study is derived sample of the annual physical examination of the SARS-CoV

infected healthcare workers. Antibody surveillance is a part of the examination. The annual physical examination has been reviewed and supported by the hospital ethics review committee. Written consent was signed at the first examination.

\subsection{SAMPLE COLLECTION}

106 A total of 362 serum samples was collected. This included samples collected at the time of hospital 
medRxiv preprint doi: https://doi.org/10.1101/2020.02.12.20021386; this version posted February 14, 2020. The copyright holder for this preprint (which was not certified by peer review) is the author/funder, who has granted medRxiv a license to display the preprint in It is made available under a CC-BY-ND 4.0 International license.

109 were missing in the follow-up (Table S2): there was an interruption of sample collection in 2012 or

1102013 due to an unexpected absence of the investigators in charge of sample collections; samples of 6

111 subjects were not collected in 2014 (Patient No. 29 - 34) and 2015 (Patient No. 26 - 28, 31-33)

112 respectively, for failing to arrange a physical examination or due to resignation. In addition, serum

113 samples from another 20 subjects, from the 95 SARS cases, were collected in 2015 (Table S3).

114 Another 40 non-SARS infected healthcare workers from the same hospital were enrolled and serum

115 samples were collected, as the control group, to verify the end result data of the 34

116 SARS-CoV-infected healthcare cohort in 2015 (Table S4).

117

\subsection{DETECTION AND QUANTIFICATION OF IgG ANTIBODIES}

118 Serum IgG antibodies were detected with a SARS-CoV IgG antibody enzyme-linked immunosorbent assay (ELISA) Kit (BGI-GBI Biotech Co. Ltd., Beijing, China), which used the whole SARS-CoV as the detection antigen. Briefly, the serum samples were added at a 1:10 diluion and incubated in pre-coated plates. After the processes of washing, reacting with HRP-labeled goat anti-human IgG, color developing, and stopping the reaction, the absorbance was measured at $450 \mathrm{~nm}$ using a plate reader. The IgG antibodies against nucleocapsid protein were detected with a recombinant SARS-CoV

124 N199 antigen assay developed in our laboratory as described previously ${ }^{21}$. Indirect ELISA was samples, as previously described by Guo et $\mathrm{al}^{21}$. 
medRxiv preprint doi: https://doi.org/10.1101/2020.02.12.20021386; this version posted February 14,2020 . The copyright holder for this preprint (which was not certified by peer review) is the author/funder, who has granted medRxiv a license to display the preprint in It is made available under a CC-BY-ND 4.0 International license.

\subsection{STATISTICAL ANALYSIS}

128 Boxplots and heatmaps were used to show the temporal trends and variations in the antibody levels.

129 Non-linear exponential decay models were used to estimate the average decay rates of the antibody

130 level. A non-parametric Mann Whitney U test was used to compare the IgG values of samples from

131 SARS-CoV-infected healthcare workers with those from the control in 2015. The test was also used to compare the anti-SARS-CoV IgG titers from SARS-CoV-infected healthcare workers who were treated with or without corticosteroids in 2003. We used the Kappa test to estimate the consistence of the results of a positive rate for both methods in the samples of the SARS-CoV-infected healthcare worker group from 2003 to 2005 and non-infected healthcare worker group in 2015. Missing values were replaced with estimated values from exponential decay models. Additionally, we conducted a comparison for the decay trend of the data with and without the missing value replacements.

\section{RESULTS}

\subsection{PROFILES OF IgG AGAINST SARS-CoV FROM 2003 TO 2015}

140 ELISA detection results showed that the IgG levels peaked in 2004, declined quickly from 2004 to

1412006 , and further decreased at a slower rate to a mean $\mathrm{OD}_{450 \mathrm{~nm}}$ value of 0.286 (against whole virus)

142 and 0.330 (against N199) in 2015 (Figure 1, A and B). IgG levels against SARS-CoV varied between

143 individuals, with the $\mathrm{OD}_{450 \mathrm{~nm}}$ range from 1.162 to 0.48 for $\mathrm{IgG}$ against whole virus, and 2.374 to

1440.581 for IgG against N199. Notably, two healthcare workers, who were diagnosed as 
medRxiv preprint doi: https://doi.org/10.1101/2020.02.12.20021386; this version posted February 14, 2020. The copyright holder for this preprint (which was not certified by peer review) is the author/funder, who has granted medRxiv a license to display the preprint in It is made available under a CC-BY-ND 4.0 International license.

146 entire study period (2003 - 2015), suggesting a possibility of misdiagnosis during the initial

147 admission in 2003; therefore, they were excluded from further statistical analyses (Figure 1, C and D).

148 The IgG levels against whole virus in 4 SARS infected healthcare workers increased notably after

149 2004, two of which also showed an increase in IgG antibodies against N199, while their levels in

150 other SARS infected healthcare workers decreased continuously during the following years (Figure 1,

$151 \mathrm{C}$ and $\mathrm{D})$.

152 In the 13-year follow-up cohort, 80 out of $442(18.10 \%)$ serum samples were lost. We used the exponential regression of curve estimation method to estimate the missing values (Figure 1). Next, we adopted the exponential decay models to define antibody decay, and the results indicated that the antibody titers exhibited an overall declining trend in IgG against both whole virus and N199 (Figure replaced in the model (Figures S1 and S2). Furthermore, the proportion of study participants with IgG

158 titer against whole virus (> cutoff value) was $81.25 \%(26 / 32)$ in 2003 , peaked at $100.00 \%(32 / 32)$ in 159 2007, and decreased to 69.23\% (18/26) in 2015 (Figure 2C). For IgG antibody against N199, the 160 initial positive (higher than the cutoff value) was $59.38 \%(19 / 32)$ in 2003 , peaked at $87.50 \%(28 / 32)$ 161 in 2005, and finally decreased to $19.23 \%(5 / 26)$ in 2015 (Figure2D). The proportion of both the IgGs 162 exhibited a reduced trend, and the higher level ( $>2$ cutoff value) declined annually until it reached $16326.92 \%$ (IgG against whole virus) and 0.00\% (IgG against N199) in 2015 (Figure 2, C and D).

164 Two healthcare workers, patient No. 11 and No. 26, who had previously been diagnosed with 
medRxiv preprint doi: https://doi.org/10.1101/2020.02.12.20021386; this version posted February 14, 2020. The copyright holder for this preprint (which was not certified by peer review) is the author/funder, who has granted medRxiv a license to display the preprint in It is made available under a CC-BY-ND 4.0 International license

166 entire study period (2003-2015). Anti-N199 IgG titers for patient No. 33 were also negative for all the

167 samples collected except the ones collected in 2005. The IgG titer against the whole virus in these patients were weakly positive. 
medRxiv preprint doi: https://doi.org/10.1101/2020.02.12.20021386; this version posted February 14, 2020. The copyright holder for this preprint (which was not certified by peer review) is the author/funder, who has granted medRxiv a license to display the preprint in

It is made available under a CC-BY-ND 4.0 International license.

$169 \quad 3.2$ DIFFERENCES IN ANTI-SARS-CoV IgG TITERS OF DIFFERENT

170 SARS-CoV-INFECTED GROUPS

171 To analyze the general IgG distributions, subjects were divided into 2 groups: group $1(\mathrm{n}=46)$,

172 including SARS-CoV-infected healthcare workers enrolled in the original cohort $(n=26)$ and

173 an additional group of SARS-CoV-infected healthcare workers who were enrolled in 2015

$174(\mathrm{n}=20)$, and group $2(\mathrm{n}=40)$ of non-infected healthcare worker, selected as the control. The

175 IgG against whole virus was above the cutoff value, and the IgG titers were significantly

176 higher in group 1 than in group $2(\mathrm{p}<0.001$; Figure $3 \mathrm{~A})$. A similar trend was observed for

177 IgG against N199 titers, as group 1 had significantly higher IgG titers than group $2(\mathrm{p}=0.034$;

178 Figure 3B). Moreover, in group 1 the positive rate of IgG binding to whole virus and N199

179 was $58.70 \%$ and $28.26 \%$ with statiscical significance $(\mathrm{p}<0.005)$, respectively.

180 Kappa test was used to estimate the consistency between the methods for testing IgG. The

181 consistency test was mainly focused on the period from 2003-2005, as the IgG titers remained

182 stable during this period. Over this period, only 10 of the 102 cases showed inconsistent

183 results between the two detection methods, and the Kappa coefficient was 0.712, suggesting a

184 good general consistence between the results obtained through the whole virus and N199

185 ELISA methods. Similarly, in the control group, only 5 of the 40 cases displayed inconsistent

186 results, and the Kappa coefficient was -0.42 , also indicating a general data consistency

187 between the two methods (Table S5). 
medRxiv preprint doi: https://doi.org/10.1101/2020.02.12.20021386; this version posted February 14, 2020. The copyright holder for this preprint (which was not certified by peer review) is the author/funder, who has granted medRxiv a license to display the preprint in

It is made available under a CC-BY-ND 4.0 International license.

188

189

190

191

193

194

195

196

197

198

199

200

201

202

203

204

205

206

207

\subsection{THE EFFECT OF CORTICOSTEROID TREATMENT ON IgG ANTIBODY}

\section{RESPONSES}

During the outbreak, some SARS-CoV-infected healthcare workers received corticosteroid treatment, while others did not. The cohort was divided into two groups to assess the effect of corticosteroid use on IgG titers in 2003. Of the 32 SARS-CoV-infected patients (with 2 cases excluded as suspected to have been misdiagnosed), medical records were available for 27 patients, and the records showed that 17 of these patients were, and the rest were not, treated with corticosteroids during the initial care for SARS in the 2002-2003 outbreak (Table S6). In SARS patients with corticosteroids treatment and those not treated with corticosteroids, the IgG against the whole virus was $0.35 \pm 0.24$ and $0.58 \pm 0.29$, respectively ( $\mathrm{p}=0.03$; Figure 4A), and the IgG against N199 was $0.56 \pm 0.40$ and $0.72 \pm 0.51$, respectively. Although IgG against N199 of patients not treated with corticosteroids were higher than those treated with corticosteroids, the difference was not statistically significant (Figure 4B; $\mathrm{p}=0.17$ ).

\section{DISCUSSIONS}

SARS was first confirmed in Guangdong, China in 2003, and subsequently became a pandemic as it spread rapidly to other countries and regions. Cases from Guangdong accounted for nearly $20 \%$ of reported cases and approximately $17 \%$ of reported healthcare worker cases worldwide. Healthcare workers, in particular, were exposed to an extremely high risk in combating SARS due to limited knowledge of the etiology and other natures of SARS outbreak. Presently, 17 years after the last SARS outbreak, a new SARS-CoV-like virus, 2019-nCoV, a new member of the betacoronavirus, is causing large scale outbreak in 
medRxiv preprint doi: https://doi.org/10.1101/2020.02.12.20021386; this version posted February 14,2020 . The copyright holder for this preprint (which was not certified by peer review) is the author/funder, who has granted medRxiv a license to display the preprint in It is made available under a CC-BY-ND 4.0 International license.

209 China. Till January 21, 2010, 440 confirmed cases have been reported in China, and several

210 cases have been reported outside China, including the USA, Japan, and Thailand.

211 Unfortunately, a large cluster of healthcare worker infections was officially reported on

212 January 20, 2020 at an early stage of this outbreak. Since information regarding this new

213 betacoronavirus outbreak remains largely unknown, evidence and knowledge from

214 SARS-CoV may provide important clues, aiding our responses to the outbreak.

215 IgG antibodies are proven to be important for virus neutralization and immunological

216 protection. As the first sampling of sera was performed during the early stage of SARS, it was

217 not possible to determine the maximum antibody titer, as this would be expected to occur

218 approximately 4 months after the onset of the outbreak. ${ }^{19}$ Knowledge of the persistence and

219 level of antibodies against SARS-CoV, particularly neutralizing antibodies, is important for

220 evaluating the immune protection duration and vaccine efficacy. Neutralizing antibodies are

221 normally tested by viral neutralization tests; however, as manipulation involving live

222 SARS-CoV is prohibited in China in the interest of preventing laboratory-acquired SARS

223 infection and potential outbreaks, an alternative approach was employed to detect specific

224 IgG antibodies using SARS-CoV whole virus as capture antigens, which has been suggested

225 in previous studies to correlate with neutralizing activity ${ }^{16}$. Moreover, the SARS-CoV N199

226 antigen was used to detect its specific antibody, which has been demonstrated to be specific in

227 clinical diagnosis and SARS-CoV reservoir screening. ${ }^{21}$ We therefore adopted the testing of

228 IgG against N199, combined with the titer analysis of $\mathrm{IgG}$ against the whole virus, to

229 comprehensively evaluate the SARS antibody duration. 
medRxiv preprint doi: https://doi.org/10.1101/2020.02.12.20021386; this version posted February 14, 2020. The copyright holder for this preprint (which was not certified by peer review) is the author/funder, who has granted medRxiv a license to display the preprint in It is made available under a CC-BY-ND 4.0 International license.

230 We found that the SARS-CoV-infected healthcare workers who were treated with

231 corticosteroids, such as prednisone and methylprednisolone, exhibited lower IgG titers during

232 the early stages of the disease than those who were not treated with corticosteroids (although

233 not significantly for IgG against N199). However, no differences were found between the two

234 groups after 2003, suggesting that corticosteroids may suppress the early production of

235 SARS-CoV IgG antibodies.

236 In our cohort, we found that two healthcare workers might have been misdiagnosed with

237 SARS, as the IgG antibodies against both the whole virus and N199 antigen was persistently

238 lower than the cutoff value, for these two patients. Notably, all the cases enrolled in this study

239 were admitted to the hospital between February and March, 2003, and that all the diagnoses

240 made before WHO's announcement that SARS-CoV was the causative agent of SARS on

241 April 16, $2003^{1}$, were based on the epidemiological features, clinical symptoms, and regular

242 laboratory blood tests, because serological and etiological diagnostic methods were not

243 available. Specifically, atypical pneumonia, as it was commonly known prior to adoption of

244 the SARS nomenclature, could also be caused by other pathogens. ${ }^{22}$ Based on the results of

245 our current 13-year serological follow-up study, it is possible that the two healthcare workers

246 might have been misdiagnosed. Thus, it warrants further investigation to clarify whether these

247 two subjects were non-responders who did not develop anti-SARS-CoV antibodies at all or

248 simply represented misdiagnosed cases. In the latter scenario, the number of SARS cases in

249 the early stage of 2002-2003 SARS outbreak may need to be reassessed. Presently, for the

250 2019-nCoV outbreak, nucleic acid-based assay and particular real time PCR, are the 
medRxiv preprint doi: https://doi.org/10.1101/2020.02.12.20021386; this version posted February 14, 2020. The copyright holder for this preprint (which was not certified by peer review) is the author/funder, who has granted medRxiv a license to display the preprint in It is made available under a CC-BY-ND 4.0 International license.

251 mainstream methods for etiological diagnosis. However, the sensitivity and specificity of

252 these assays need careful evaluation, because any false positive or negative results might be

253 harmful to the subjects.

254 During the SARS outbreak, the typical SARS patients mainly presented with antibodies

255 positive for SARS-CoV, fever, and symptoms of respiratory tract infections. Additionally,

256 there was a small group of asymptomatic SARS-CoV-nfected subjects, who only presented

257 with antibodies positive for SARS-CoV, but showed an absence of clinical symptoms. ${ }^{23-25}$. In

258 this study, we found that four subjects had an abnormal increase in the titers of SARS-CoV

259 antibodies during the follow-up. In contrast, the titers of SARS-CoV antibodies in most of the

260 other healthcare workers appeared to decrease slowly. It is unclear if these four healthcare

261 workers were reinfected with SARS-CoV or other coronaviruses with no signs or symptoms.

262 Thus, further investigation is needed to clarify whether these healthcare workers elicited IgG

263 response by SARS-CoV or other coronaviruses. In the former situation, the novel mechanism

264 of IgG generation without the clinical SARS symptoms needs to be elucidated.

265 Although IgG against SARS-CoV declined from 2003 to 2015 gradually, IgG levels in

266 SARS-CoV-infected healthcare workers were significantly higher than those in the

267 non-infected healthcare workers control group in 2015. The infected cases enrolled into the

268 study in 2015, exhibited detectable IgG against whole virus, and the positive rate was $\sim 60 \%$.

269 For IgG against N199, the positive rate was $\sim 30 \%$ in 2015 . Moreover, results of the

270 exponential decay curve revealed that $\operatorname{IgG}$ antibodies against the whole virus were positive

271 throughout the 13-year follow-up, while IgG antibodies against N199 were negative only in 
medRxiv preprint doi: https://doi.org/10.1101/2020.02.12.20021386; this version posted February 14, 2020. The copyright holder for this preprint (which was not certified by peer review) is the author/funder, who has granted medRxiv a license to display the preprint in It is made available under a CC-BY-ND 4.0 International license.

2722015.

273 Collectively, based on our results, we can infer that the IgG against SARS-CoV can persist at

274 least for 12 years. Presently, we are unaware whether the persistent IgG antibodies possess

275 virus neutralization activities and can provide complete protection against SARS-CoV

276 infection or cross protection against the new betacoronavirus, 2019-nCoV. From previous

277 studies, we predicted that the presence of IgG antibodies could at least provide a partial

278 protection against coronavirus infection. These data will be valuable for better understanding

279 the immune mechanisms and vaccine development strategies against SARS-CoV and

280 2019-nCoV, therefore being helpful for responses against the ongoing coronavirus outbreak. 
medRxiv preprint doi: https://doi.org/10.1101/2020.02.12.20021386; this version posted February 14, 2020. The copyright holder for this preprint (which was not certified by peer review) is the author/funder, who has granted medRxiv a license to display the preprint in It is made available under a CC-BY-ND 4.0 International license.

285 We thanks collaborators participating in sample collection during the cohort study. This work

286 is supported by Guangdong Province Key Area R \& D Plan Project (2018B020241002). analysis. 


\section{References}

300

301

302

303

304

305

306

307

308

309

310

311

312

313

314

315

316

317

318

319

320

321

322

323

324

325

326

327

328

329

330

331

332

333

334

335

336

337

338

339

1. Peiris JS, Yuen KY, Osterhaus AD, Stohr K. The severe acute respiratory syndrome. N Engl J Med 2003;349:2431-41.

2. Drosten C, Gunther S, Preiser W, et al. Identification of a novel coronavirus in patients with severe acute respiratory syndrome. N Engl J Med 2003;348:1967-76.

3. Xu C, Wang J, Wang L, Cao C. Spatial pattern of severe acute respiratory syndrome in-out flow in 2003 in Mainland China. BMC Infect Dis 2014;14:721.

4. Al-Ahdal MN, Al-Qahtani AA, Rubino S. Coronavirus respiratory illness in Saudi Arabia. J Infect Dev Ctries 2012;6:692-4.

5. Centers for Disease C, Prevention. Prevalence of IgG antibody to SARS-associated coronavirus in animal traders--Guangdong Province, China, 2003. MMWR Morbidity and mortality weekly report 2003;52:986-7.

6. Hsin DH, Macer DR. Heroes of SARS: professional roles and ethics of health care workers. J Infect 2004;49:210-5.

7. Chen WQ, Lu CY, Wong TW, et al. Anti-SARS-CoV immunoglobulin G in healthcare workers, Guangzhou, China. Emerg Infect Dis 2005;11:89-94.

8. Organization WH. China's latest SARS outbreak has been contained, but biosafety concerns remain - Update 7, 18 May 2004. 2007.

9. Kondro W. Canadian officials watch SARS-like mystery bug. Lancet 2003;362:714.

10. Guan Y, Zheng BJ, He YQ, et al. Isolation and characterization of viruses related to the SARS coronavirus from animals in southern China. Science 2003;302:276-8.

11. Ge XY, Li JL, Yang XL, et al. Isolation and characterization of a bat SARS-like coronavirus that uses the ACE2 receptor. Nature 2013;503:535-8.

12. Fields B, Knipe D, Howley P. Fields virology. 5th. Philadelphia: Wolters Kluwer Health/Lippincott Williams \& Wilkins; 2007.

13. Li F, Li W, Farzan M, Harrison SC. Structure of SARS coronavirus spike receptor-binding domain complexed with receptor. Science 2005;309:1864-8.

14. Zaki AM, van Boheemen S, Bestebroer TM, Osterhaus AD, Fouchier RA. Isolation of a novel coronavirus from a man with pneumonia in Saudi Arabia. N Engl J Med 2012;367:1814-20.

15. Memish ZA, Cotten M, Meyer B, et al. Human infection with MERS coronavirus after exposure to infected camels, Saudi Arabia, 2013. Emerg Infect Dis 2014;20:1012-5.

16. Liu L, Xie J, Sun J, et al. Longitudinal profiles of immunoglobulin G antibodies against severe acute respiratory syndrome coronavirus components and neutralizing activities in recovered patients. Scandinavian journal of infectious diseases 2011;43:515-21.

17. Liu W, Fontanet A, Zhang PH, et al. Two-year prospective study of the humoral immune response of patients with severe acute respiratory syndrome. J Infect Dis 2006;193:792-5.

18. Xie SY, Zeng G, Xia SC, et al. A three-year follow-up study on sera specific antibody in severe acute respiratory syndrome cases after the onset of illness. Zhonghua Liu Xing Bing Xue Za Zhi 2007;28:343-5.

19. Cao WC, Liu W, Zhang PH, Zhang F, Richardus JH. Disappearance of antibodies to SARS-associated coronavirus after recovery. N Engl J Med 2007;357:1162-3. 
medRxiv preprint doi: https://doi.org/10.1101/2020.02.12.20021386; this version posted February 14, 2020. The copyright holder for this preprint (which was not certified by peer review) is the author/funder, who has granted medRxiv a license to display the preprint in It is made available under a CC-BY-ND 4.0 International license.

340 20. Wang H, Jiang S, Wang E, Zhou X, Li Y, Zhao M. Follow-up study on serological detection of 341 anti-SARS-CoV IgG/IgM antibody and its significance. Infectious Disease Information 2009:235-7.

342 21. Guo ZM, Lu JH, Han WY, et al. Comparison of effectiveness of whole viral, N and N199 proteins, 343 by ELISA for the rapid diagnosis of severe acute respiratory syndrome coronavirus. Chinese Medical 344 Journal 2007;120:2195-9.

345 22. Liu YN, Tian Q, Hu H, et al. Misdiagnostic analysis of clinically diagnosed severe acute 346 respiratory syndrome after following up 197 convalescent patients. Chin Med J (Engl) $3472005 ; 118: 1487-9$.

348 23. Wilder-Smith A, Teleman MD, Heng BH, Earnest A, Ling AE, Leo YS. Asymptomatic SARS 349 coronavirus infection among healthcare workers, Singapore. Emerg Infect Dis 2005;11:1142-5.

350 24. Woo PC, Lau SK, Tsoi HW, et al. Relative rates of non-pneumonic SARS coronavirus infection 351 and SARS coronavirus pneumonia. Lancet 2004;363:841-5.

352 25. Ip M, Chan PK, Lee N, et al. Seroprevalence of antibody to severe acute respiratory syndrome 353 (SARS)-associated coronavirus among health care workers in SARS and non-SARS medical wards. 354 Clin Infect Dis 2004;38:e116-8.

355 26. Deng W, Wang Y, Liu Z, Cheng H, Xue Y. HemI: a toolkit for illustrating heatmaps. PLoS One 356 2014;9:e111988. 
medRxiv preprint doi: $h t$ tps://doi.org/10.1101/2020.02.12.20021386; this version posted February 14, 2020. The copyright holder for this preprint (which was not certified by peer review) is the author/funder, who has granted medRxiv a license to display the preprint in

A IgG against SARS-CoV whole virus

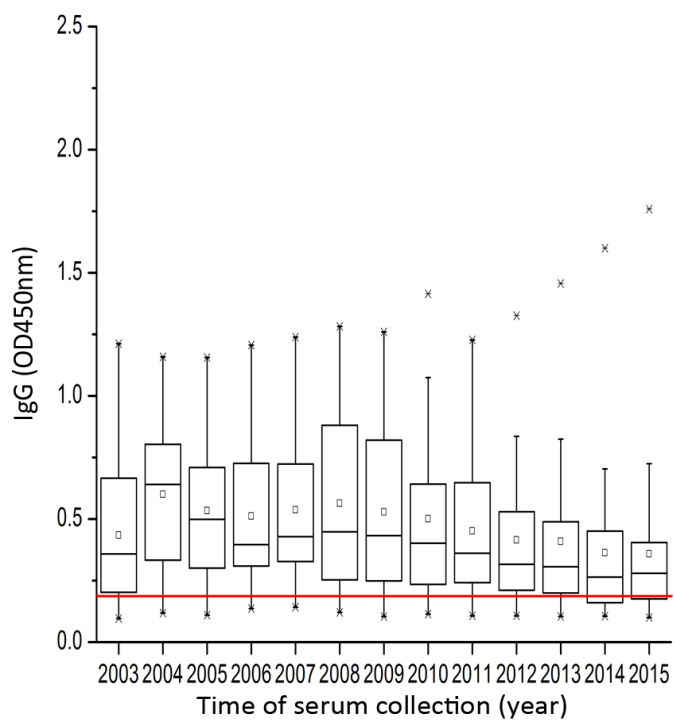

C IgG against SARS-CoV whole virus

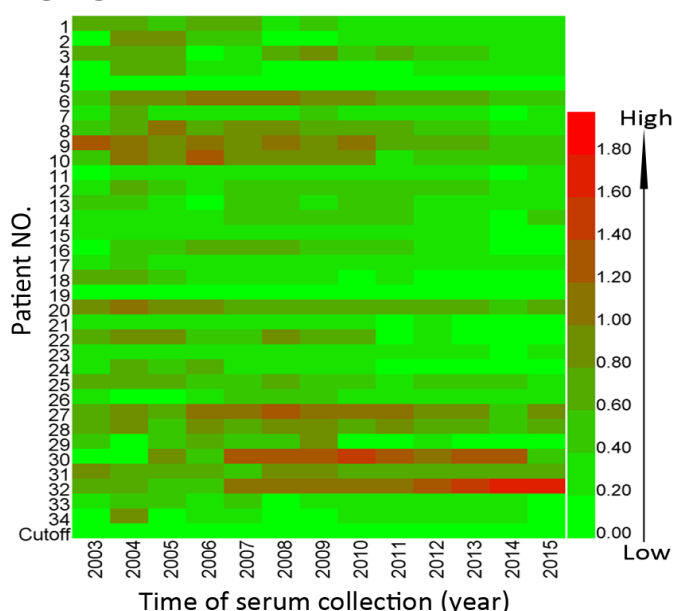

B IgG against SARS-CoV N199

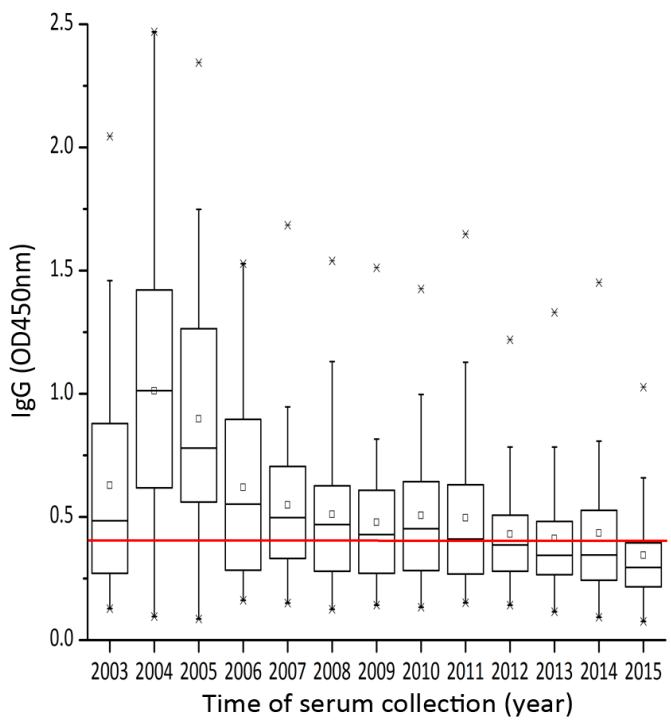

D IgG against SARS-CoV N199

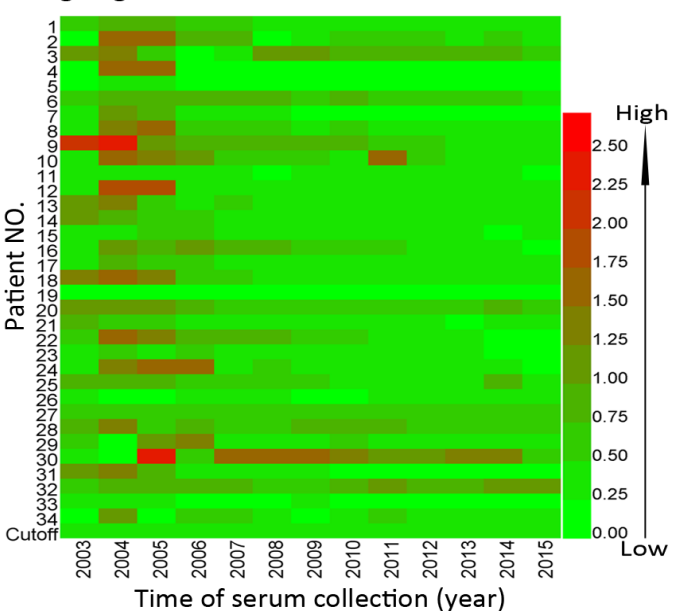

Figure 1. Temporal changes in IgG antibodies against SARS-CoV whole virus and N199 in

(A) The levels of IgG antibodies using SARS-CoV whole virus as antigen for ELISA detection. The boxplot displays the IgG titers of the 25 th, $50^{\text {th }}$, and 75 th percentiles. The whiskers extend to the most extreme data point $<1.5$ times the inter-quartile range. The cutoff value (red lines) was defined at 0.19 according to the manufacturer's instructions for the SARS-CoV whole virus ELISA kit. Eighty samples lost during follow up were estimated for their reading values using exponential regression of curve estimation method (The same as below). (B) Levels of IgG antibodies against SARS-CoV N199. The cutoff value (red lines) was calculated as follows: cutoff $=$ mean of $\mathrm{OD}_{450 \mathrm{~nm}}$ from 52 general population serum samples $+3 \times$ standard deviations, which gave a value of 0.40 . (C) The dynamics of IgG against SARS-CoV whole virus of each individual, from 2003 to 2015, illustrated by heatmap (HemI 1.0, 
medRxiv preprint doi: https://doi.org/10.1101/2020.02.12.20021386; this version posted February 14, 2020. The copyright holder for this preprint (which was not certified by peer review) is the author/funder, who has granted medRxiv a license to display the preprint in

It is made available under a CC-BY-ND 4.0 International license.

376

2003 to 2015 .

377

378

379 
medRxiv preprint doi: $h t$ tps://doi.org/10.1101/2020.02.12.20021386; this version posted February 14, 2020. The copyright holder for this preprint (which was not certified by peer review) is the author/funder, who has granted medRxiv a license to display the preprint in

It is made available under a CC-BY-ND 4.0 International license.

A Exponential decay curve for IgG against whole virus
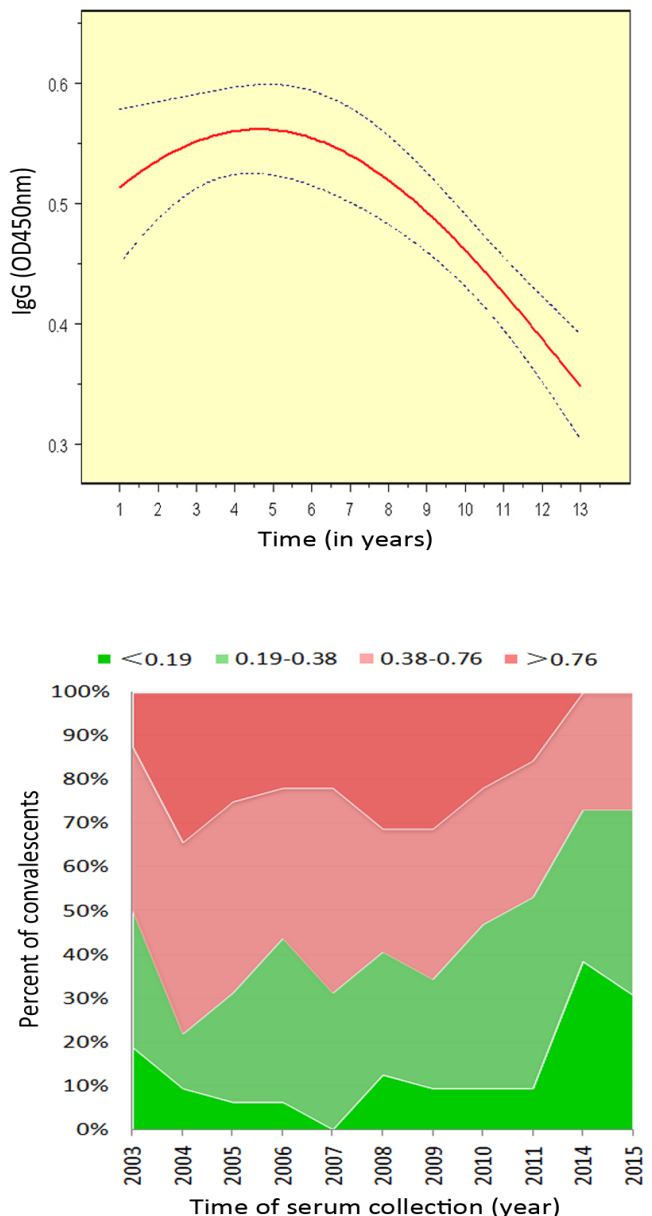

B Exponential decay curve for IgG against N199
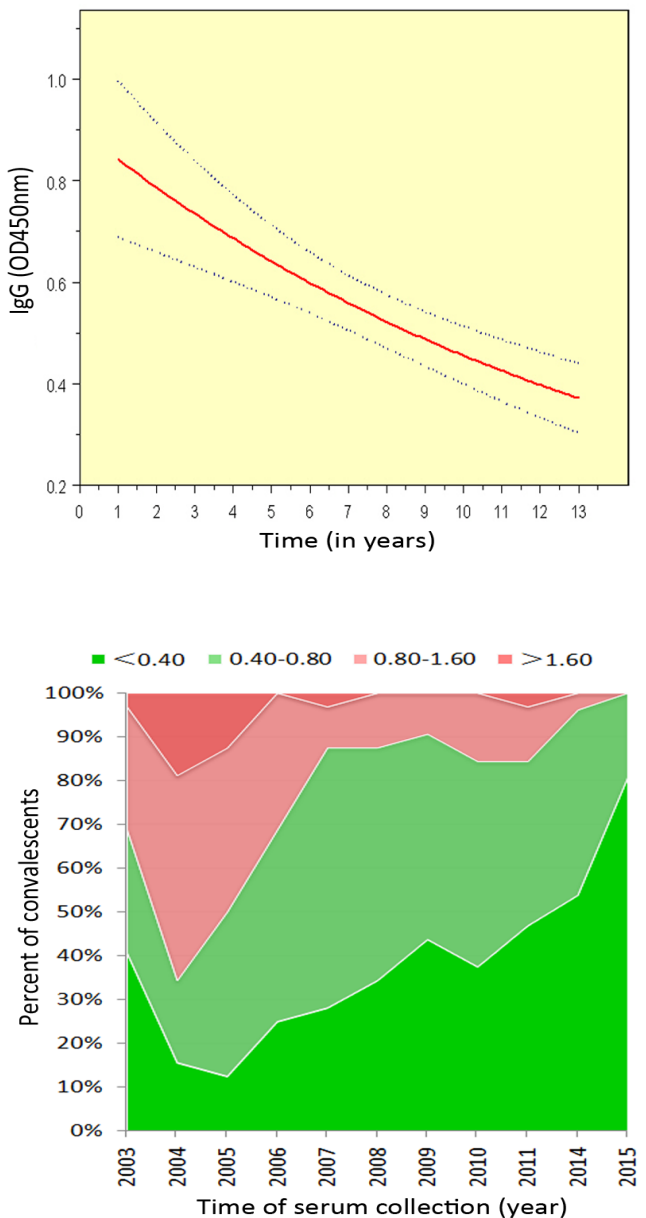

Figure 2. Population profiles of IgG against SARS-CoV whole virus and N199 from 2003 to 2015

382 (A) Predicted mean (red line) with 95\% confidence limits (blue lines) of IgG against whole virus in the cohort from 2003 to 2015. Eighty specimens lost during follow up were estimated for the missing values using the exponential regression of curve estimation method (The same as Panel B). (B) Predicted mean with 95\% confidence limits of IgG against N199 in the cohort from 2003 to 2015. (C) Proportions of different ranges of IgG against SARS-CoV whole virus in the SARS-CoV-infected healthcare workers. (D) Proportions of different ranges of IgG against SARS-CoV N199 in SARS-CoV-infected healthcare workers. 
medRxiv preprint doi: $h t$ tps://doi.org/10.1101/2020.02.12.20021386; this version posted February 14, 2020. The copyright holder for this preprint (which was not certified by peer review) is the author/funder, who has granted medRxiv a license to display the preprint in perpetuity.

It is made available under a CC-BY-ND 4.0 International license .

A IgG against SARS-COV whole virus

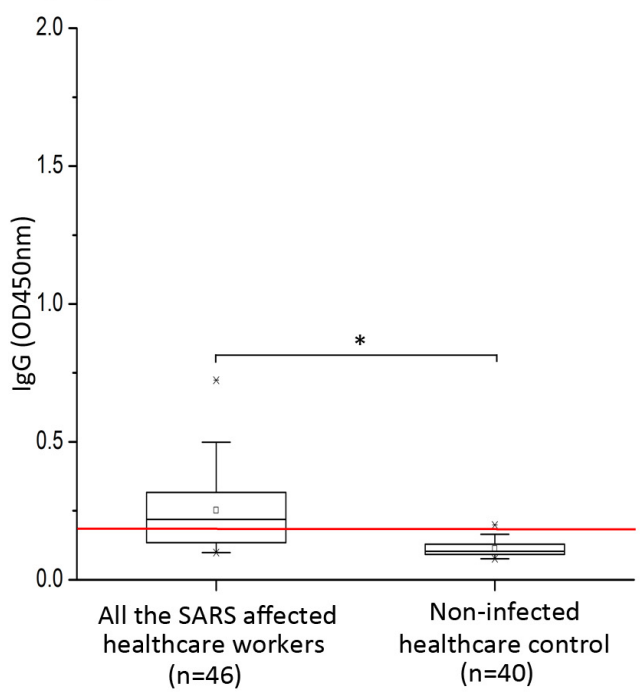

B IgG against SARS-CoV N199

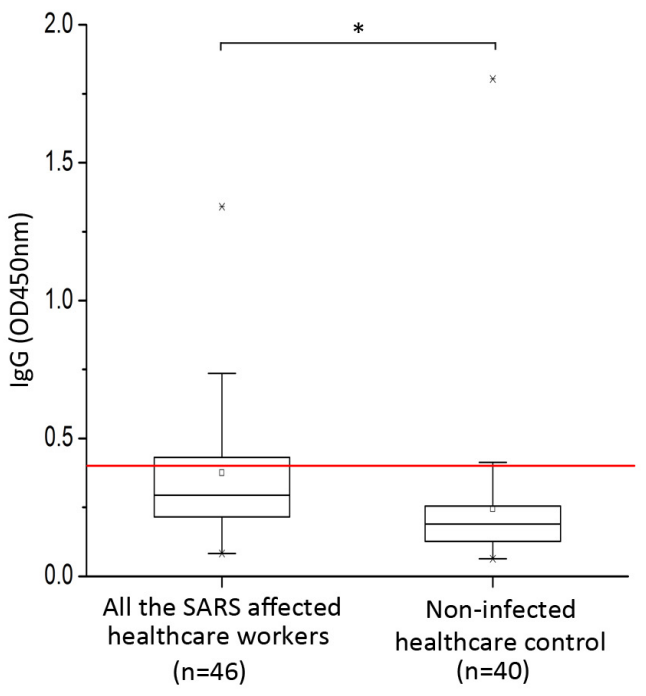

Figure 3. Distributions and differences of IgG in SARS-infected and non-infected healthcare 393 workers (control)

394 (A) The distributions and differences of IgG antibodies against SARS-CoV whole virus between all 395 SARS-CoV-infected $(n=46)$ and non-infected healthcare workers (control) enrolled in $2015(n=40)$. 396 The boxplot displays the IgG titers of the 25th, 50th, and 75th percentiles. The whiskers extend to the 397 most extreme data point $<1.5$ times the inter-quartile range. The red line represents the cutoff value 398 (0.19). (B) The distributions and differences of IgG antibodies against SARS-CoV N199 between all 399 the SARS-CoV-infected ( $\mathrm{n}=46)$ and non-infected healthcare worker controls enrolled in $2015(\mathrm{n}=40)$. 400 The red line is the cutoff value (0.40). $P$ value of $<0.05$ (two-tai) is considered to be statistically 401 significant $(*)$. 
medRxiv preprint doi: https://doi.org/10.1101/2020.02.12.20021386; this version posted February 14, 2020. The copyright holder for this preprint (which was not certified by peer review) is the author/funder, who has granted medRxiv a license to display the preprint in

It is made available under a CC-BY-ND 4.0 International license

404

405

A IgG against SARS-CoV while virus

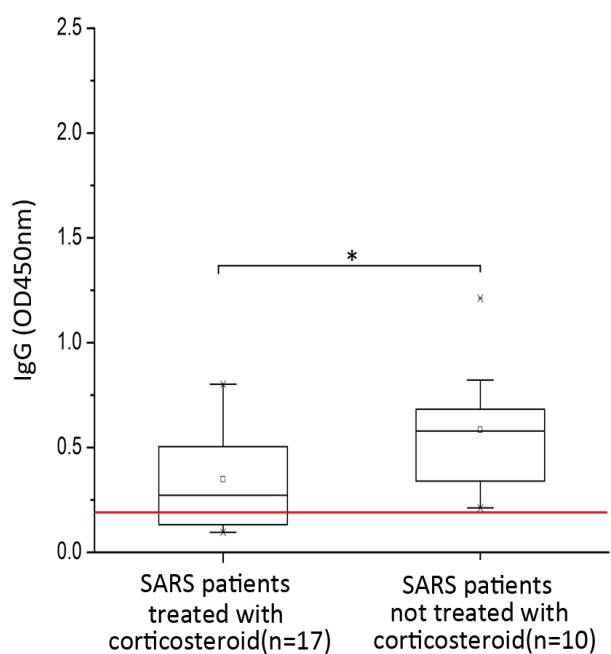

B IgG against SARS-CoV N199

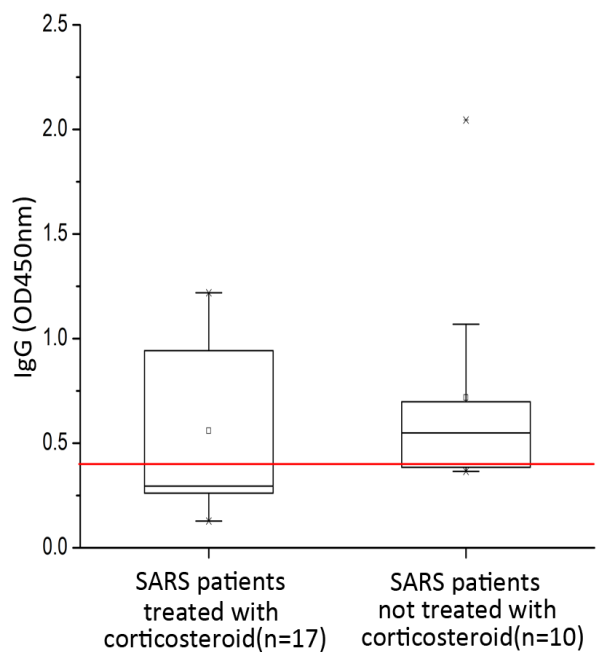

Difference in IgG titers against SARS-CoV whole virus (A) or SARS-CoV N199 antigen (B) between SARS-infected healthcare workers treated with or without corticosteroids. The boxplot displays the IgG titers of the 25th, 50th, and 75th percentiles. The whiskers extend to the most extreme data point Figure 4B), $P$ value of $<0.05$ (two-tai) is considered to be statistically significant $(*)$. 
medRxiv preprint doi: $h t$ tps://doi.org/10.1101/2020.02.12.20021386; this version posted February 14, 2020. The copyright holder for this preprint (which was not certified by peer review) is the author/funder, who has granted medRxiv a license to display the preprint in perpetuity.

It is made available under a CC-BY-ND 4.0 International license.

\section{Supplementary Appendix}

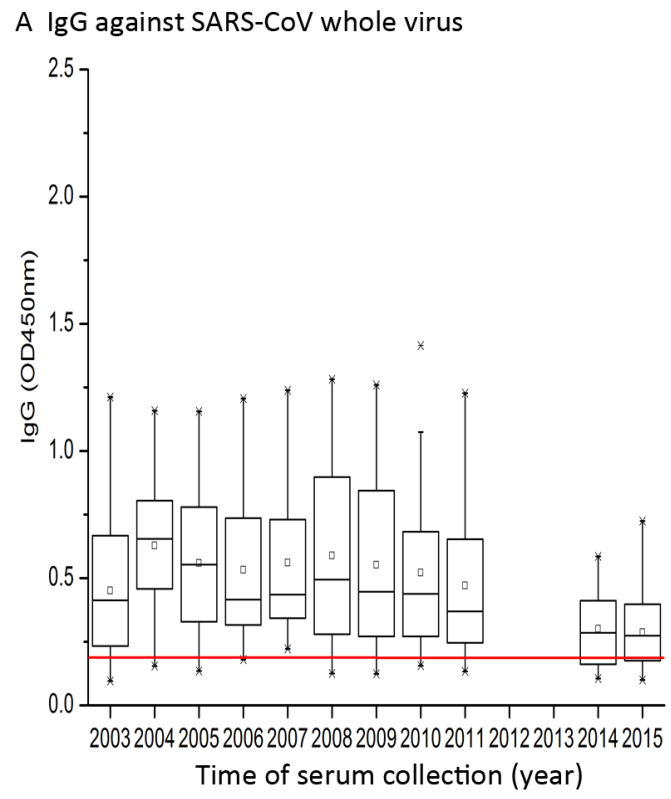

C IgG against SARS-CoV whole virus

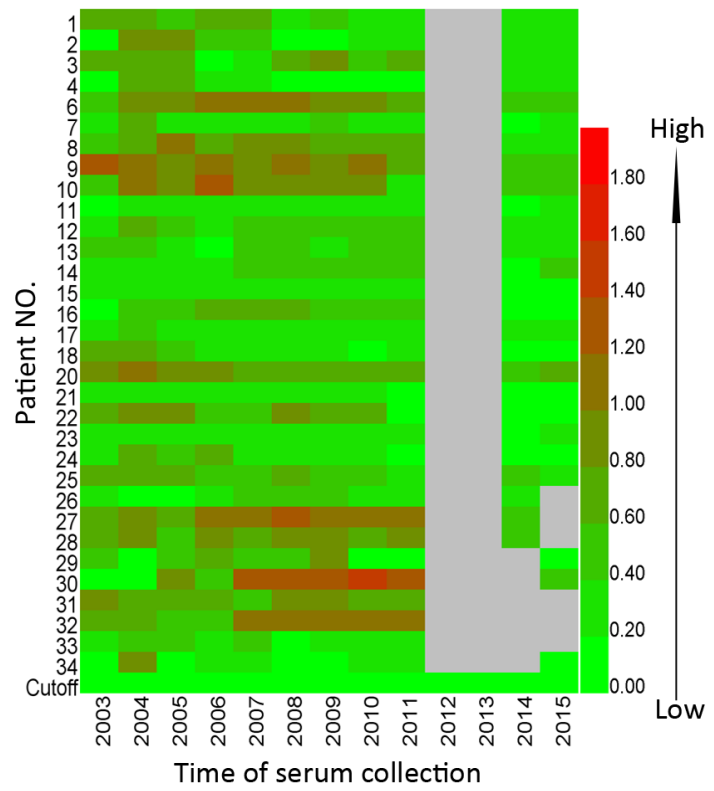

B IgG against SARS-CoV N199

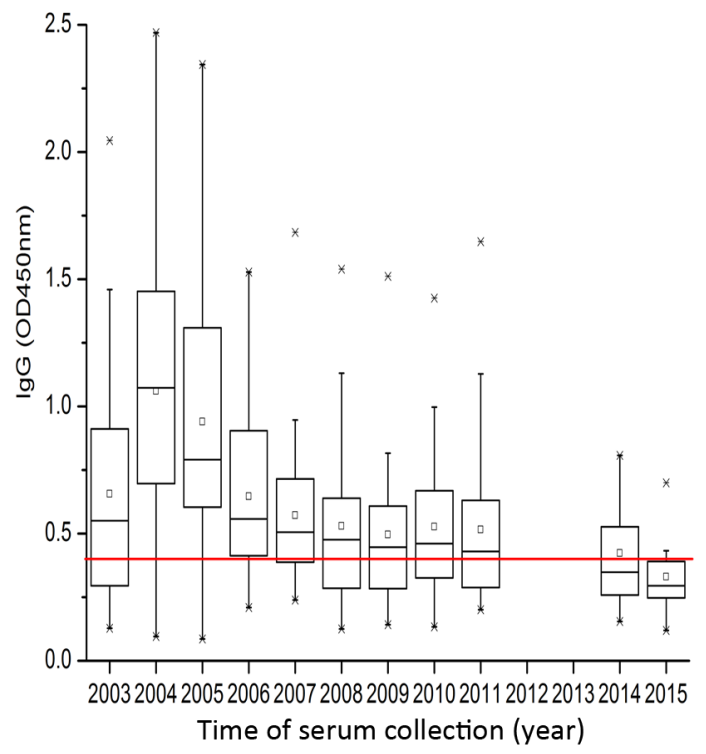

D IgG against SARS-CoV N199

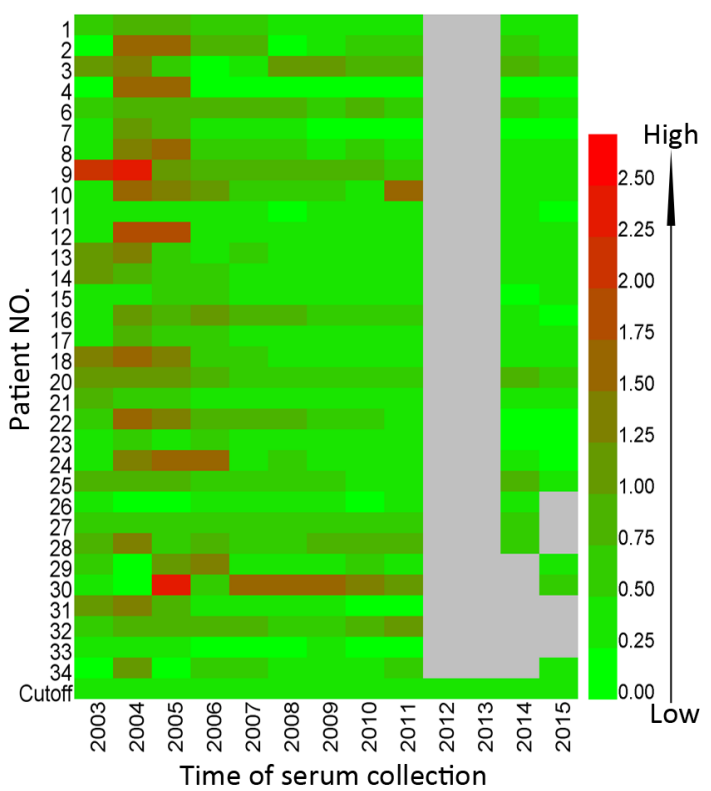

Figure S1. Temporal changes in IgG antibodies against SARS-CoV whole virus

423 (A) Level of IgG antibodies against SARS-CoV whole virus. The boxplot displays the IgG tiers of 
medRxiv preprint doi: https://doi.org/10.1101/2020.02.12.20021386; this version posted February 14, 2020. The copyright holder for this preprint (which was not certified by peer review) is the author/funder, who has granted medRxiv a license to display the preprint in It is made available under a CC-BY-ND 4.0 International license.

424 the 25 th, 50th, and 75 th percentiles. The whiskers extend to the most extreme data point $<1.5$

425 times the inter-quartile range. The cutoff value (red line) was defined as a value of 0.19 according

426 to the manufacturer's instruction of the SARS-CoV whole virus ELISA kit. (B) Levels of IgG

427 antibodies against SARS-CoV N199. The cutoff value (red line) was calculated as follows: cutoff

$428=$ mean of $\mathrm{OD}_{450 \mathrm{~nm}}$ from 52 general population serum samples $+3 \mathrm{X}$ standard deviations, which

429 gave a value of 0.40 . (C and D) dynamics of IgG titers against SARS-CoV whole virus (C) or

430 SARS-CoV N199 (D) of each individual from 2003 to 2015 by the method described above.

431 Gray blanks represent the serum samples lost.

432

433 
medRxiv preprint doi: $h t$ tps://doi.org/10.1101/2020.02.12.20021386; this version posted February 14, 2020. The copyright holder for this preprint (which was not certified by peer review) is the author/funder, who has granted medRxiv a license to display the preprint in It is made available under a CC-BY-ND 4.0 International license.

434

A Exponential decay curve for IgG against whole virus

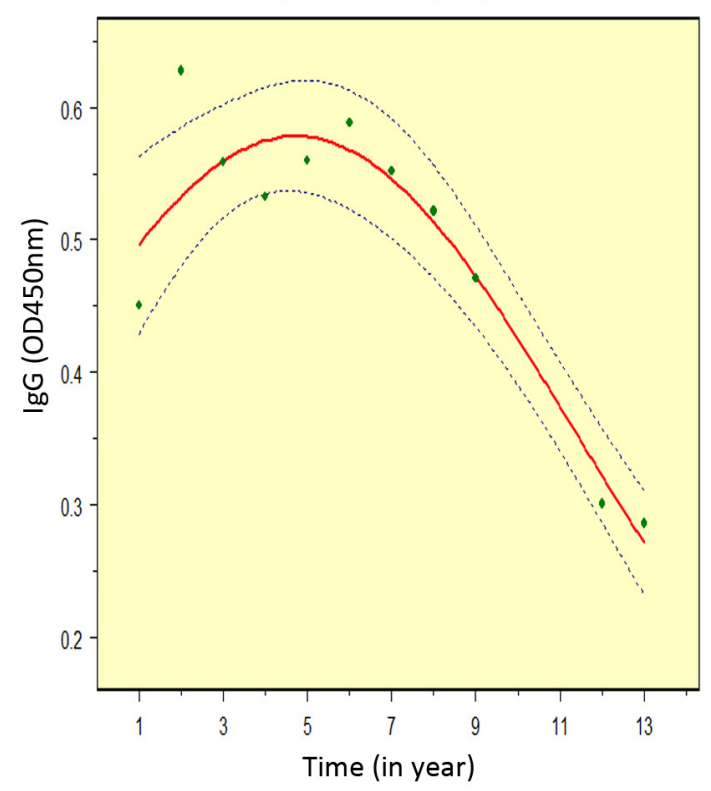

B Exponential decay curve for IgG against N199

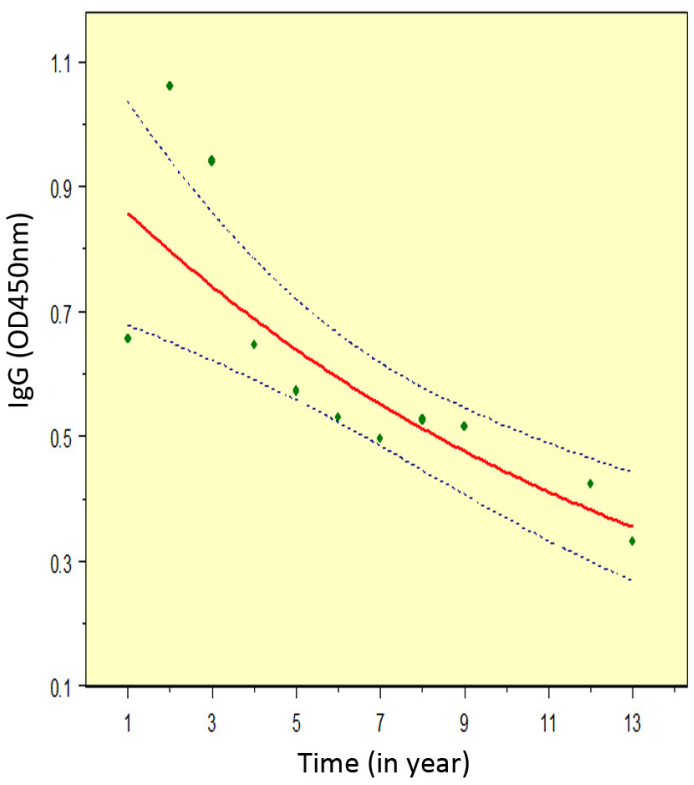

436 Figure S2. Predicted means of titers of IgG against SARS-CoV whole virus and 